\title{
Practice Teaching Innovation on Tourism Management Major of Middle Vocational Undergraduate
}

\author{
Hongyan Liu \\ College of Finance and Trade, Bohai University, Jinzhou, 121013, China \\ 47203209@qq.com
}

\begin{abstract}
Keywords: middle vocational undergraduate; tourism management major; practice teaching; innovative ways
\end{abstract}

\begin{abstract}
Practice teaching is the teaching theory of value, is the need of modern tourism talents cultivation, in the teaching of tourism management major has an irreplaceable role. First of all, analyzing on the problems existed in the secondary vocational undergraduate tourism management professional practice teaching; Then, build a secondary vocational undergraduate tourism management professional practice teaching system, and finally, the secondary vocational undergraduate tourism management major professional practice teaching innovation way. Specific ways include: establish a stable off-campus practice teaching base, integrated practical course system according to the practice teaching target, improve the ability of students to find and solve problems, turn the "three stage" model into "practice oriented" model, the formation of tourism management professional practice teaching new levels.
\end{abstract}

\section{Introduction}

Practice teaching is that colleges and universities according to their own professional training goal, consolidate the theoretical knowledge and an effective way to deepen understanding of the theory, is to cultivate innovative important link of high-quality engineering and technical personnel, is the theory with practice, cultivate students to master the scientific method, and the important platform for improving practice ability. It is conducive to improve students' quality and the formation of the correct values. Through practice, causes the student to obtain perceptual knowledge skills training, improve the comprehensive quality, and cultivate the innovative spirit. Tourism management as a practical applied science, the cultivation of the talent must have a strong practical ability and the ability to deal with emergencies strain. Therefore, the practical teaching in the teaching of tourism management has an irreplaceable role. Strengthen students' practical operation ability, training students' strong ability of practice and social adaptation ability is one of the tourism professional talents facing the major issue. Existing institutions of the country's tourism management is basically realized the important position of practical teaching in the cultivation of talents, combined with their own teaching characteristic and professional characteristics, increase the content of the practical teaching in the teaching plan, in order to improve the quality of talent training, actively adapt to market demand for talents.

Tourism is a comprehensive service industry, which has the very broad borderline and fusion. Aiming at cultivating applied talents of tourism management professional, practical teaching has irreplaceable function [1]. It is because of the practical and comprehensive characteristics of tourism, the requirements for talents industry development must be to have a solid theoretical foundation and skilled operation skills of comprehensive talents. Secondary vocational undergraduate course is run in recent years, new undergraduate education level, and with vocational education characteristics, practice teaching is the most important link in the process of secondary vocational teaching of undergraduate course. In order to improve the teaching effect of secondary vocational undergraduate tourism management experiments carried out in this paper, the research and to cultivate qualified tourism management professional and technical personnel of the service. 


\section{Practice Teaching Existing Problems on Tourism Management Major of Middle Vocational Undergraduate}

Through detailed investigation and analysis, combined with the related references, this paper summarizes the problems existing in the tourism management professional practice teaching in secondary vocational is as follows:

(1) Practice teaching is not enough. Tourism specialty practice teaching is as "adjuvant" curriculum, tradition that "give priority to with the teacher lectures" education mode, the lack of practice teaching, also does not have the targeted and systematic practice teaching plan. Pay attention to the abstract theoretical knowledge, practical ability, application ability and innovation ability are not development exercise. Existing in the practical teaching theory teaching, practice teaching, and even could do without some of the ideas of practice teaching.

(2) Teachers' practice skills are not high. The critical of practice teaching link can do well is decided by the teachers' level. Teachers engaged in the work of practice teaching, it is necessary to have a combination of solid theoretical knowledge and outstanding ability of the business. Many professional tourism practice teaching professional teachers, theoretical foundations, but lack of professional practice experience, professional skills, practical ability, practical ability, practical ability and teaching are at a disadvantage.

(3) Lack of practice teaching link of institutionalized management [2]. Practice teaching is broad, it is necessary to coordinate the relationship between many aspects of the campus off-campus. Relative to the theoretical teaching, practical teaching management is more difficult. But the reality is that most schools have no strict standard management, unreasonable appraisal way behind, management system, the management conceptions is larger, the problems such as nonstandard operation procedures, a single achievement appraisal way, it is difficult to reflect the real condition of practice teaching.

(4) The outside school practice in a state of disorder. Only school and tourism enterprises to maintain good relations of cooperation, the students can regularly into the practice of enterprise. But companies pursuing economic benefits, in the present practice teaching mode, difficult to short-term involved in the enterprise operation, difficult to create economic benefits for the enterprise. Students into the enterprise simply learn to experience, the accumulation of practical experience for students has brought great limitations. The enthusiasm of students and teachers to practice will abate, out of the original starting point.

\section{Practice Teaching System Construction on Tourism Management Major of Middle Vocational Undergraduate}

Practical teaching system is made of the practice teaching activity each element organic connection as a whole, is the integration of the main way to cultivate students' practical ability [3]. Not only provide teachers with the clear teaching train of thought, also provides powerful guarantee for training talents. General practice teaching system is composed of the elements of practice teaching activity of organic whole, including the practice teaching goal system, content system, implementing way system, management system and guarantee system, such as elements, elements in their work, and coordination, play the overall function of practice teaching system. Narrow practice teaching system refers to the practice teaching content system, namely around the goal of talent cultivation, in making the teaching plan, through the curriculum and the practice teaching link configuration is established and the content of the theoretical teaching system in full accord system.

Establishment of practical teaching system should follow the following principles: principles, characteristic as the driving force of the existence and development of the school, secondary vocational undergraduate should take quality education as the core, technology applied ability training as the main line, strain ability as the key, as the way of combining study and continuous innovation in practice; The practical principle, to fully embody the requirements of professional posts, closely related to professional post group development, build a distinct practical teaching 
system, a clear division of responsibilities; Hybrid principle, including the type of teacher mixing, theory teaching and practice teaching, the classroom and laboratory mix, downplay theory teaching and practice teaching, professional teachers and practice guidance teachers, classrooms and laboratories boundaries, to practice teaching facility, readjusting the integration combined practice teaching mode. According to the characteristics of the secondary vocational undergraduate tourism management of building practical teaching system is shown in Fig. 1.
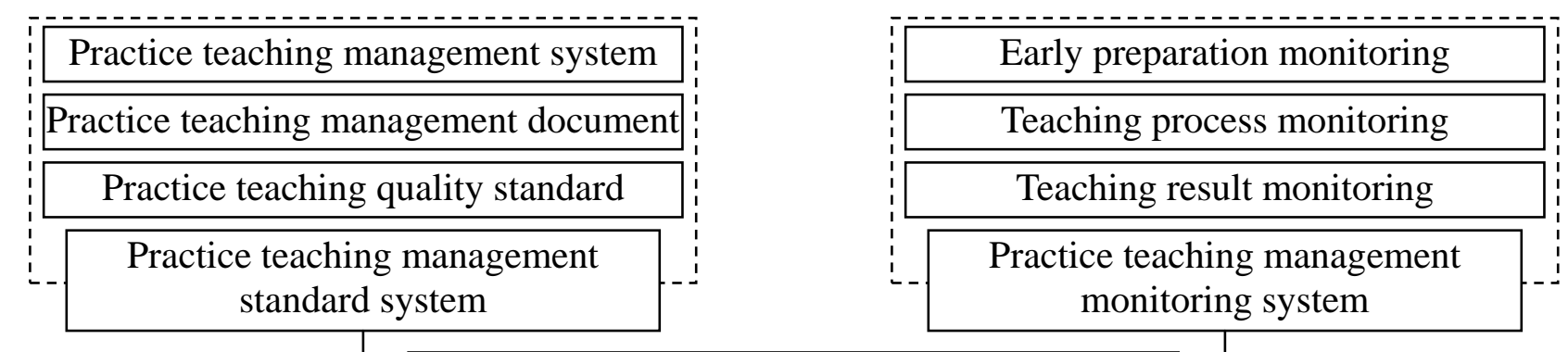

Practice teaching system on tourism management

major of middle vocational undergraduate

Practice teaching management
feedback system

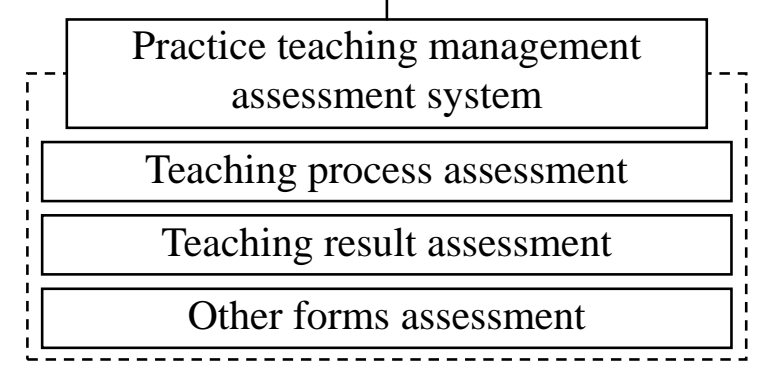

Fig. 1. Practice teaching system on tourism management major of middle vocational undergraduate

(1) Practice teaching management standard system. Including three aspects: one is that the practice teaching management system, standardizing the teaching management staff is code of conduct, including the regulations for the teaching management system, practice and experiment teaching management, etc.; The second is, the practice teaching management files, standardizing the teacher's teaching is code of conduct, including practice teaching outline, teaching plan and teaching instruction, etc.; Three is that the practice teaching quality standard, is to test students' practical measure of teachers' teaching quality and learning effect, including curriculum design quality standards and the experimental teaching quality standards, etc.

(2) Practice teaching management monitoring system. Has a purpose and a plan to monitor every link of practice teaching, the original qualitative and abstract goal decomposition and further embodiment, formation can be directly used to accurately measure the practice teaching process and effect of operation of the operating system [4]. Including three aspects: one is that preparation monitoring, including practical arrangements and learning preview, etc.; The second is, the teaching process monitoring, including situation and learning practice under the guidance of teachers, etc.; Three is, teaching the results of monitoring, including teacher performance evaluation and the distribution of grades.

(3) Practice teaching management evaluation system. Practice teaching appraisal is the practice teaching quality evaluation results, is one of the basic way to examine students' professional quality and professional ability. Based on the practice teaching goal, through the test cultivation of students' professional quality, professional skill mastery possess a degree or level and professional ability, and then measure the practice teaching effect [5]. Including three aspects: one is that assessment of teaching process, including specification and operation process, etc.; The second is the teaching result evaluation, including experimental results and the experiment report, etc.; Three is that other forms of assessment, including practical skills competition and innovation design competition, etc.

(4) Practice teaching management feedback system. Feedback is the basic concept of cybernetics, to back to the input and the output of a system to change the input in some way, and thus affects the 
process of the system function, the output through the appropriate detection device to return to the input end and comparing with input process. Practical teaching management feedback system mainly includes three aspects: one is that the teaching process feedback, the feedback back to the problems in the teaching process; The second is, the teaching result feedback, feedback to the problems existing in the teaching result; Three is, unit of choose and employ persons feedback, feedback back to unit of choose and employ persons found problems.

\section{Practice Teaching Innovation Ways on Tourism Management Major of Middle Vocational Undergraduate}

Innovation is a uniquely human cognitive ability and practice ability, is the human subjective initiative of high performance and the inexhaustible driving force of promoting national progress and social development. If a nation wants to go in the time front row, is also not a moment without innovation thinking, there's not a moment to stop all kinds of innovation. Practice of conventional teaching method and the system can not meet the needs of the secondary vocational undergraduate tourism management talents cultivation, combining previous research results [6-8], this paper puts forward the innovative way of the following:

(1) Establish stable off-campus practice teaching bases. Off-campus practice teaching base construction is dependent on the resources, including the funds investment, teacher and hardware input, etc., enterprises should play a guiding role of the resource input, provide a solid material guarantee, colleges and universities in spiritual culture leads and theoretical guidance plays a bigger role. Off-campus practice teaching base depends on the linkage of the college and enterprise cooperation mechanism, the government should play a leading role, to enact corresponding policies to promote the cooperation between colleges and clear the rights and duties in the relationship between each other, provide a powerful policy guarantee; To do well in the daily management of the enterprises and colleges and universities in the division of labor, establish a coordination area, enhance the sense of responsibility of both sides; Use of social forces to monitor the running status of practical teaching base of greater openness and transparency, meet the market demand.

(2) Integrated practical course system according to the practice teaching target. Merger or cancel the repetitive experiments, increasing comprehensive and designing experiments, and to realize the integration of practice teaching; Each link of practice teaching activity goes through the whole process of learning, building has to undertake in time complement each other, the function of practice teaching system, and make the practice on time and cooperate with each other in the best state, realize the whole course of practice teaching; According to cognitive practice, basic skills training, professional skills training, professional comprehensive ability training and so on four ladder, step by step to arrange practical teaching link, strengthening the practice teaching of progressive; To ability training as the main line to build the new practice teaching content system, according to the principle of theory with practice scientifically arrange the practice teaching link.

(3) Improve the ability of students to find and solve problems. Tourism industry is approved by the calm in face of difficulty, the thought is agile, can calm to analyze and solve problems. Many graduates think is not good and have a problem hard in paraphrase books theory, make the advantage of higher education cannot into full play in practical work. Practical teaching activity, therefore, should pay attention to arouse the students' initiative, actively guide students thinking, good at discovering, improve the problem found acuity and solving ability. Best method is to let students work, and the problems in the process of practice to make the right guidance. Otherwise it will cause students professional knowledge mixed, unable to adapt to the development of tourism industry.

(4) Turn the "three stage" model into "practice oriented" model. "Three-step" course pattern is usually the curriculum is divided into three categories, namely the cultural basic course, professional basic course and the comprehensive practice course. Teaching process is divided into three stages, learning culture basic course first, then learn professional basic course, finally complete the comprehensive practice course. "Practice oriented" requirements: entrance education to make students into the tourism work practice, to enter the first character, inspire the love for the 
professional, cause learning professional interest, cultivate social responsibility consciousness; Professional courses before, organizes the student to the tourism enterprises practice, the formation of a perceptual knowledge of the professional, and related skills training and then into the professional course learning; To alternate between professional theory and professional practice class, to learn the theory, organizes the student to practice or drill or skills in a timely manner, to realize the mutual promotion of theory and practice.

(5) Formation of new tourism management professional practice teaching level. It includes cognitive level, control level, arrangement of teaching level and ability, the natural process that accords with the cognitive learning and ability training of general order. Through cognitive based on practice training, make the students understand the professional tourism management, a basic knowledge of professional thinking and writing power of expression; By campus industry skills practice and social comprehensive practice, raising students' capability of tourism product planning and marketing ability, tourism market analysis and information technology application ability; Training skills development practice, through the bilingual teaching and professional competition, for students to exercise platform; Through the professional preparation and professional scientific research practice, exercise the students' ability of research and application. This way not only ensures the integrity of the practice teaching, and highlights the various stages of the focus; Is beneficial to the student individuality development, and ensures the overall optimization of teaching.

\section{Conclusion}

Tourism management professional to cultivate good professional quality and professional skill, can plan travel, can in travel agencies, hotels and other related tourism enterprises engaged in the service and management of high-quality talent. Practice teaching is the teaching theory of value, is the need of modern tourism talents cultivation, is the need of cultivating students' good professional ethics, is the important way to realize university-enterprise cooperation [9]. Professional practice of the specific purpose is not only a basic service skills, also includes professional consciousness training, familiar with the industry environment, and understanding of tourism activities in the human relations and on the investigation to the tourism industry actual management activities and the trainee. In this paper, the research results play an important role in guiding to improve secondary vocational undergraduate tourism management professional practice teaching.

\section{Acknowledgement}

This work is supported by social science planning fund project of Liaoning province (L15BJY010).

\section{References}

[1] Q. Gao, Y. J. Feng, L. Ding, "On the practice teaching innovation of tourism management major," Journal of Educational Institute of Jilin Province, vol. 31, no. 4, pp. 36-39, 2015.

[2] Y. Yu, "Research on practice teaching of Tourism Management Specialty Based on ability training," Journal of Kaifeng Institute of Education, vol. 35, no. 6, pp. 148-149, 2015.

[3] H. H. Zhang, X. P. Li, F. Zhao, et al., "Literature review on the research of practical teaching system," Cultural and educational materials, vol. 56, no. 1, pp. 143-146, 2013.

[4] Y. G. Gao, "Exploration on the management of practice teaching quality and the construction of monitoring system," Journal of Hebei University of Engineering (Social Science Edition), vol. 29, no. 3, pp. 104-106, 2012.

[5] H. Y. Lu, R. C. Wang, E. H. Shang, L. Dai, "Research and application of the evaluation system of practical teaching in higher vocational education," Journal of Heilongjiang Vocational Institute of Ecological Engineering, vol. 23, no. 5, pp. 69-74, 2010. 
[6] C. H. Zhang, Y. Yang, "Research on the practice teaching reform of application oriented specialty," Contemporary Vocational Education, vol. 6, no. 2, pp. 26-29, 2015.

[7] W. J. Shao, "Study on the Tourism Management Undergraduate Practical Teaching Base Construction," Master's degree of Shenyang Normal University, 2014.

[8] X. B. Guo, "Research on Tourism Management Teaching System of Higher Vocational Colleges in Henan Province," Master's degree of Zhengzhou University, 2013.

[9] Q. Z. Wang, "Probe into the Problems Existed in the Practical Teaching in the Subject of Tourism Management," Journal of Inner Mongolia Finance and Economics College, vol. 4, no. 2, pp. 69-72, 2006. 